
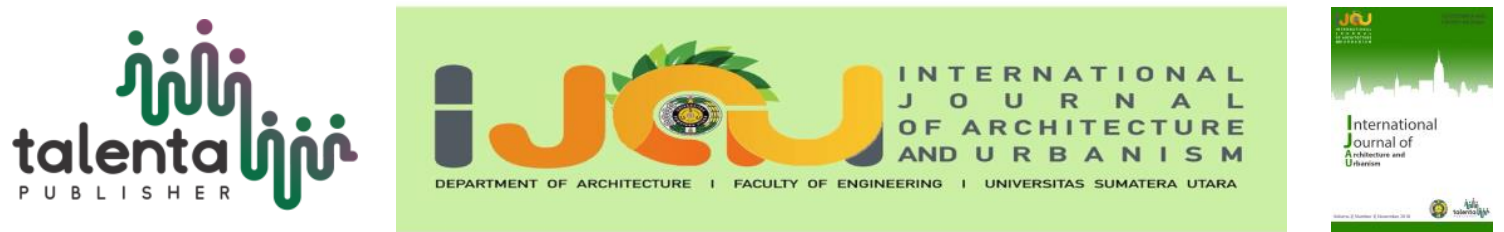

\title{
Hotel Resort in Chinatown Medan Labuhan Area
}

\author{
Muhammad Juanda ${ }^{*}$, Nelson M. Siahaan ${ }^{1}$ \\ ${ }^{1}$ Architecture Department, Faculty of Engineering, Universitas Sumatera Utara, Medan, Indonesia
}

\begin{abstract}
The development of the historic area in Medan Labuhan requires hotels that meet the standards of domestic and foreign tourists. Tourism development is noteworthy because tourism services include the leading sector in the national economy. As an effort to develop new tourism area, Cultural Heritage Area in Medan Labuhan is a historical tourism area that has the potential to be visited by tourists both domestic and foreign tourists. For this thesis proposed design "Hotel Resort in Chinatown Medan Labuhan Area." So the resort hotel design approach uses the theme of Vernacular Architecture because the location of the design has an intense relationship with the Heritage Buildings especially Taopekong building. This thing is to reinvigorate the identity of this Chinatown Region like its heyday by making a resort hotel that blends with the old building. The research method used is ethnography method with qualitative data collection. Data collection was obtained from the literature study, field survey, comparative study, and group discussion. So Hotel Resort is the best solution to develop Medan Labuhan Area. With the facilities provided are old building store area, function room, bar \& lounge, restaurant, cafe, swimming pool, playground, artificial lake \& cottages.
\end{abstract}

Keyword: Hotel resort, labuhan, vernacular

\section{Introduction}

Medan Labuhan area located between the city of Medan \& Belawan has a lot of potentials to be developed as a development center of North Medan City. One of the potency that must be promoted in this area is the development of tourism area. Cultural tourism of Medan city is set in building area of Maimun Palace at BWP ${ }^{1}$ Medan Maimun, area of Great Mosque in BWP Medan City, the old building on Kesawan Street in BWP Medan Barat, residential area and railway warehousing at BWP Pulo Brayan Bengkel BWP East Medan, and Labuhan Old Town Area at BWP Medan Labuhan.

Therefore, in the area of cultural tourism in the Old Town Region in Medan Labuhan needed to be improved an inn as an effort to accommodate tourists who will tour the history of the old

\footnotetext{
${ }^{1}$ BWP : Badan Perencanaan Wilayah (Part of Planning Area)
}

\footnotetext{
*Corresponding author at:Department of Architecture, Faculty of Engineering, Universitas Sumatera Utara, Jalan Perpustakaan Gedung J07, Medan 20155, Indonesia

E-mail address: muhammadjuanda07@ gmail.com
} 
town of Medan Labuhan, such as:/ Pekong Shop homes, Al-Osmani Mosque, Vihara Siu Sian Kong and Labuhan Railway Station. So the development of Labuhan Deli area gives a prominent role to the development of the city of Medan itself. This expansion can increase city revenue, to increase the value of tourism in Medan City and can introduce the historic building of Medan City.

Designing a Resort Hotel in Chinatown Medan Labuhan is to support the running of tourism activities in the area of old buildings and to improve the economy of Chinatown Medan Labuhan. So that resort hotels are needed to accommodate tourists because this area will be used as an integrated area that will become the center of various activities in Medan Labuhan area. Then it is proposed the function of resort hotels as lodging facilities in this area in the form of hotels that blend with the shophouses as a Cultural Heritage that can be used as a place to vacation and relax for foreign tourists and local tourists who will visit the Hotel Resort in Chinatown Medan Labuhan. This design is based on analyzes derived from literature studies and comparative studies.

Location of Resort Hotel in Medan Chinatown Medan Labuhan located in Medan Labuhan District is a district situated in Medan City which has an area of about 36.67 $\mathrm{km}^{2}$ or $13.83 \%$ of the total area of Medan with a population of 111,173 inhabitants. The location of the design is in the way of Syahbudin Yatim, Medan Labuhan Sub District Pekan Labuhan. Boundaries on the place, namely: in the north there Deli River, the eastern and western part there are settlements, and in the southern part, there is the way Syahbudin Yatim. The land is designed to have a land area of 16,000 $\mathrm{m} 2$ (Figure 1).

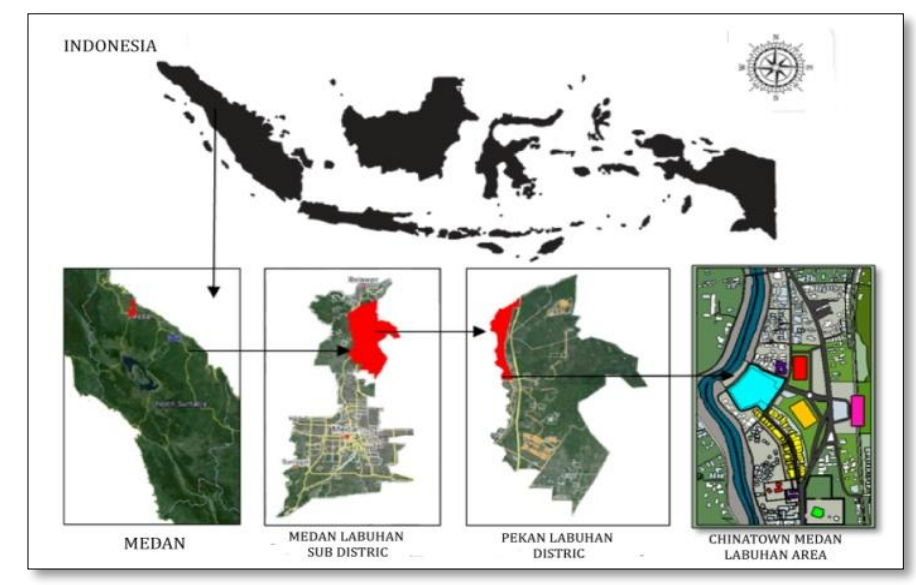

Figure 1. Site Location

\section{Literature Review}

The theme chosen for the Hotel Resort planning project in Chinatown Medan Labuhan is a Vernacular theme that discusses the typical Vernacular Architecture of Chinatown Medan Labuhan Area. So the existence of ancient buildings that exist in this area can be used as 
an attraction for tourists. The old building is a monument that will survive because it is a historic building that is still functional [1]. Unfortunately, some parties including the government have not been able to capture the existence of existing Chinese colonial buildings as assets that can be used as one of the local cultural treasures. Implementation of this theme is also implemented to maintain tradition and modernity. Tradition and modernity are two sides of the coin, both of which determine the value of a change in society.

The application of vernacular architecture is currently widely used for buildings whose functions are not in accordance with their original functions. The vernacular building is packed into more modern forms and functions with the addition of modern material but does not leave its essence as a local building. This shows that vernacular architecture has been popularly applied in society. Chinatown in Medan Labuhan has a very strong culture of Malay and Chinese so that the application of Chinatown and Malay cultural contexts can be applied through vernacular themes. Therefore still consider modern materials so that the culture around this area can be applied to the design of Resort Hotels in the Medan Labuhan Chinatown. If you look at the Medan Labuhan context, this area is right to be used as an integrated tourism area that preserves old buildings as one of the attractions for tourists.

\section{Methodology}

The research method used in the design of Hotel Resort in Chinatown Medan Labuhan area is qualitative \& quantitative research methods produced through interviews and observation / direct survey to the existing location. So the selection of design location is based on the Building and Environmental Management Plan (RTBL) ${ }^{2}$ Chinatown Area Medan Labuhan. Based on the Building and Environment Plan, the design site is intended for several functions, namely services and trade, transportation services, and health services. Location Resort Hotel in Chinatown Medan Labuhan area is in the Heritage Area so that the achievement of the site is divided into two, namely using a vehicle or on foot. The circulation of transport to the design site passes the Syahbudin Yatim road as a secondary arterial road which becomes an alternative road to the site and is a road connected to the Yos Sudarso road. This street is a two-way street, and there is no stipulation of public transportation that can pass this way and also poor pedestrian is on its sidewalk. Land on this project is a residential land with a population of 1.6 Hectares.

Conditions at the current design site consist of vacant land, and residents' homes. The location area is in the middle of the settlement with $1 / 2$ hour travel time from downtown Medan using public transportation or private vehicle. The location is just 15 minutes from Belawan port by

\footnotetext{
${ }^{2}$ RTBL : Rencana Tata Bangunan dan Lingkungan (Building and Environmental Management Plan)
} 
private transportation and has a general transportation center that is Labuhan Train Station (Figure 2).

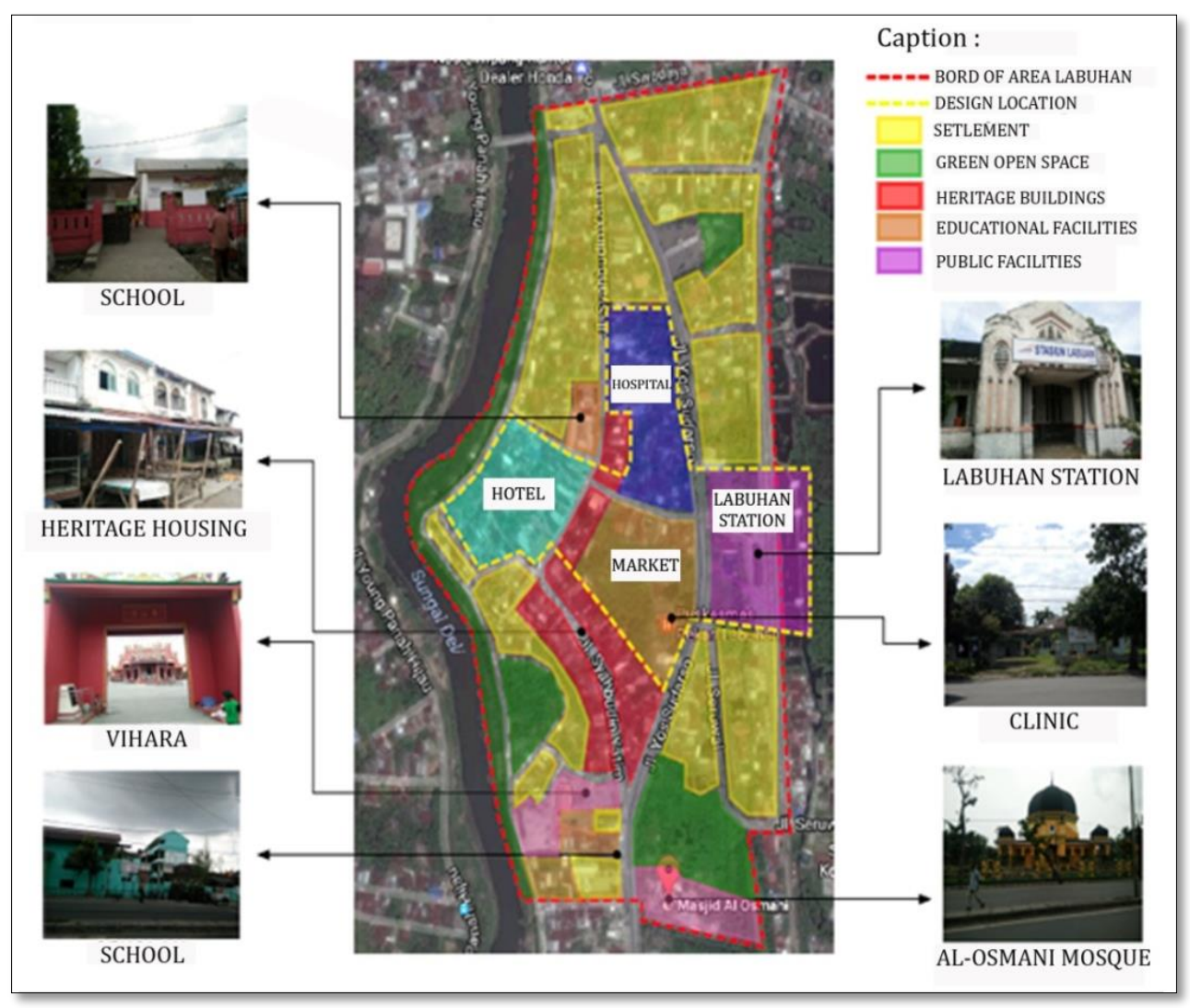

Figure 2. Existing on Site

Hotel Resorts in Chinatown Medan Labuhan area is aimed to meet the desire of visitors, namely: comfort, resting opportunities with calm, privacy, and physical and mental satisfaction. These demands can be met by architectural design completion and segregation of activities taking place within the hotel.

\section{Results and Discussion}

The basic concept in the design of this resort hotel exploit the potential of the Heritage area as part of a typical resort hotel Chinatown Medan Labuhan area so that the basic concept of the hotel blends with the old buildings in this area to become a resort hotel in a planned area that is not just to stay but also relaxation and recreation (Figure 3). 


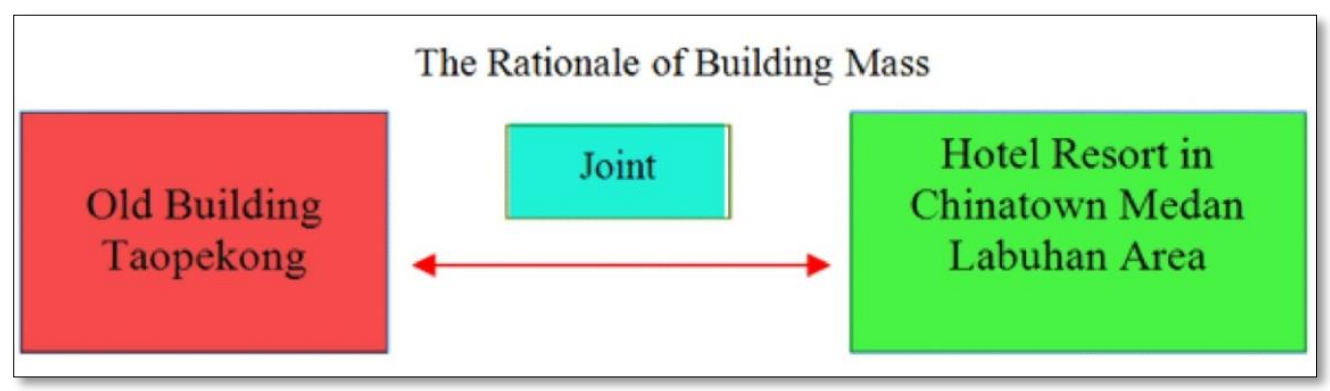

Figure 3. Basic Concept of Building Mass Scheme

\section{The Concept of Zoning}

The design zone division based on the applicable regulations are:/ road borderline of at least four meters and with a maximum height of five floors (Figure 4).

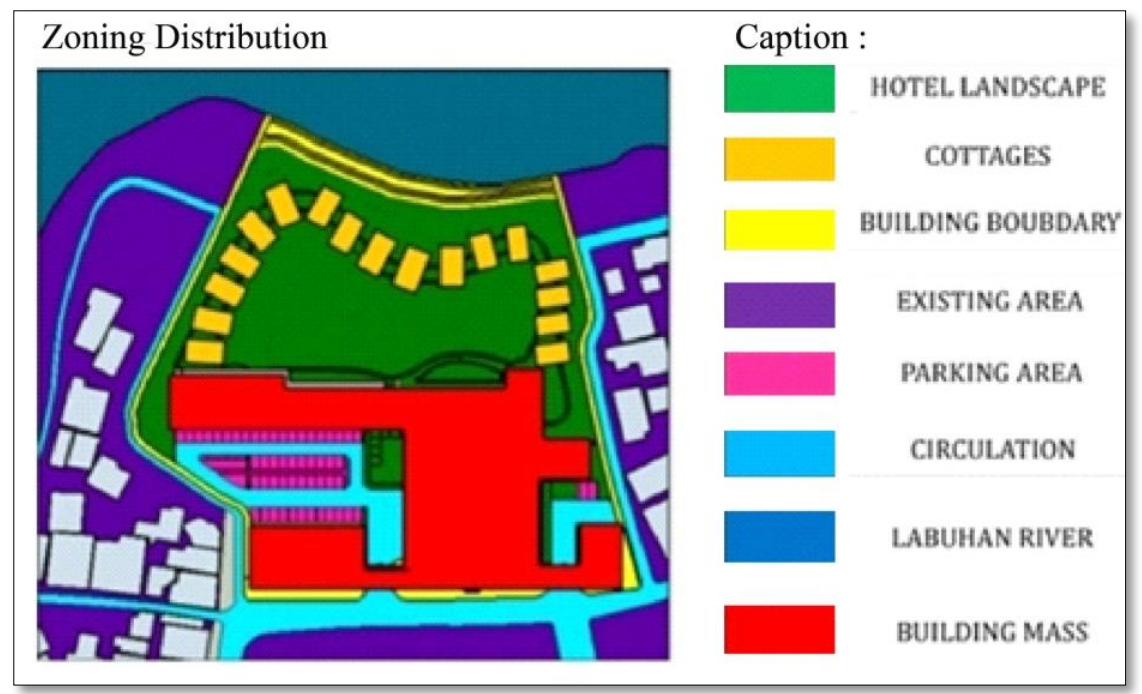

Figure 4. Outer Space Zone Distribution

\section{The Concept of Composition Mass}

The concept of a mass composition formed by observing the orientation of the sun, wind, noise, and vegetation to create a form of the mob structure like this and at the front of the hotel is designed to join the old Taopekong building. Buildings are made elongated so that winds can enter the hotel openings. The building can also respond to the sun with a typical Chinatown roof that can block the sun's heat (Figure 5). 


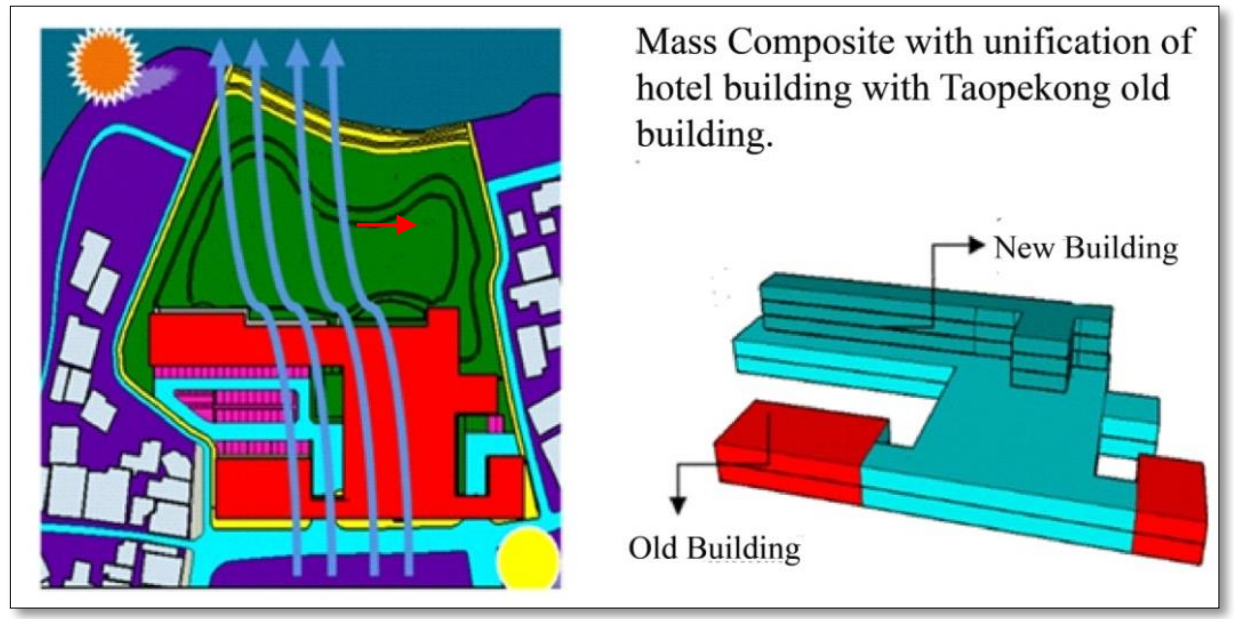

Figure 5. The Concept of Composition Mass

\section{The Concept of Circulation}

In the design of the site, there are two entrances vehicles with the division of the path circulation visitors and circulation path manager \& service. The division of two lanes is done to facilitate the circulation of vehicles so as not to cause congestion in front of Syahbudin Yatim road (Figure 6).

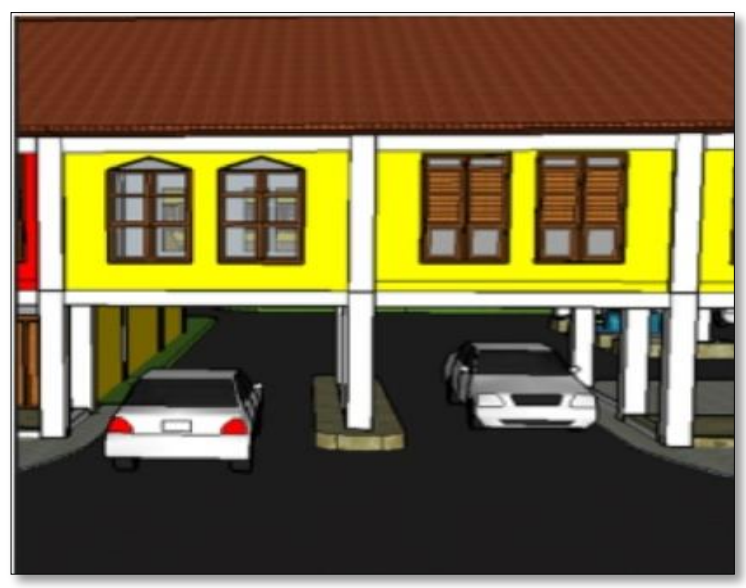

Figure 6. Concept of Circulation

\section{The Concept of Space Hierarchy}

The concept of the space hierarchy space on the inside of the hotel is applied by separating the hierarchy of space in hotel resort with the following scheme (Figure 7). 


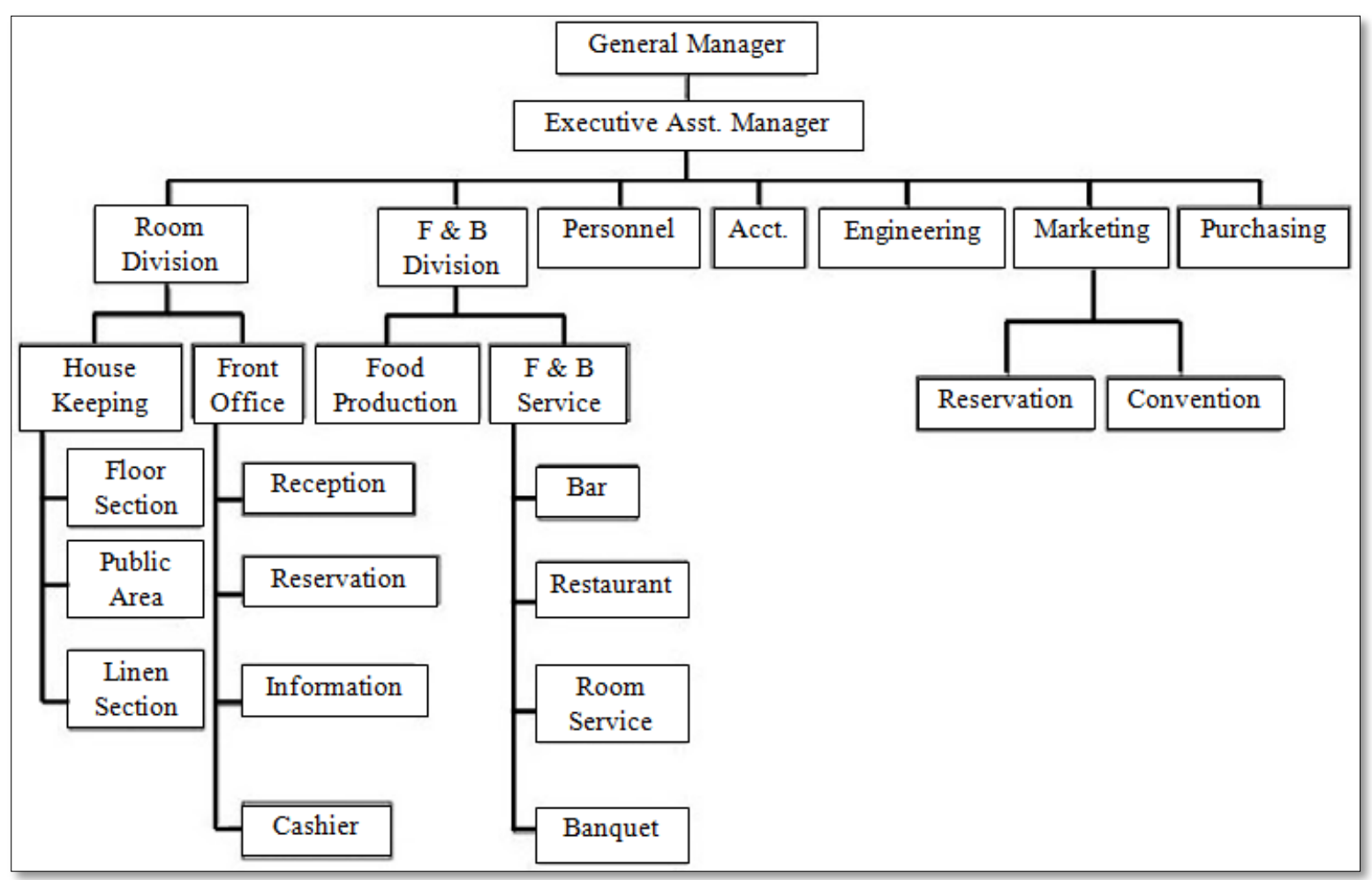

Figure 7. Space Relations Scheme

Space Relations Scheme is divided into several parts, namely; General Manager, Executive Assistant Manager, Room Division, Food \& Beverage Division, Engineering, Marketing, Purchasing, and Accounting [2].

\section{The Concept of Building Typology Form}

Activities at this resort hotel include: Staying activity is the primary activity and very dominant at the hotel because with this activity hence planned room concept which varies in hotel design. Other activities of many resort hotels are recreation and relaxation activities in the hotel and the area surrounding the hotel. So the hotel is a means of public housing for tourists by providing room service, food, and beverage providers as well as accommodation with payment terms. The shape of the building pattern adopted the form of a typology of the heritage building in the area of Medan Labuhan[3] (Figure 8).

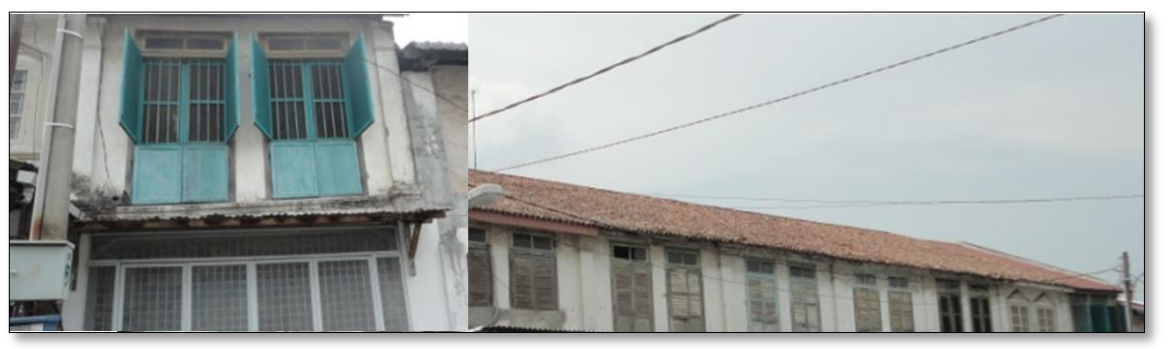

Figure 8. Building Typology Form 


\section{The Concept of Zoning Division}

The concept of zoning division in Hotel Resort in Chinatown Medan Labuhan area has four parts, namely: Private zone is a zone in which is a personal area such as rooms \& cottages on the hotel. Public zone is public spaces like lobby, lounge, restaurant, cafe \& concession area. The semi-public zone is like a swimming pool, function room, fitness area, spa \& sauna. And service zones such as loading dock, kitchen, housekeeping, and others (Figure 9).

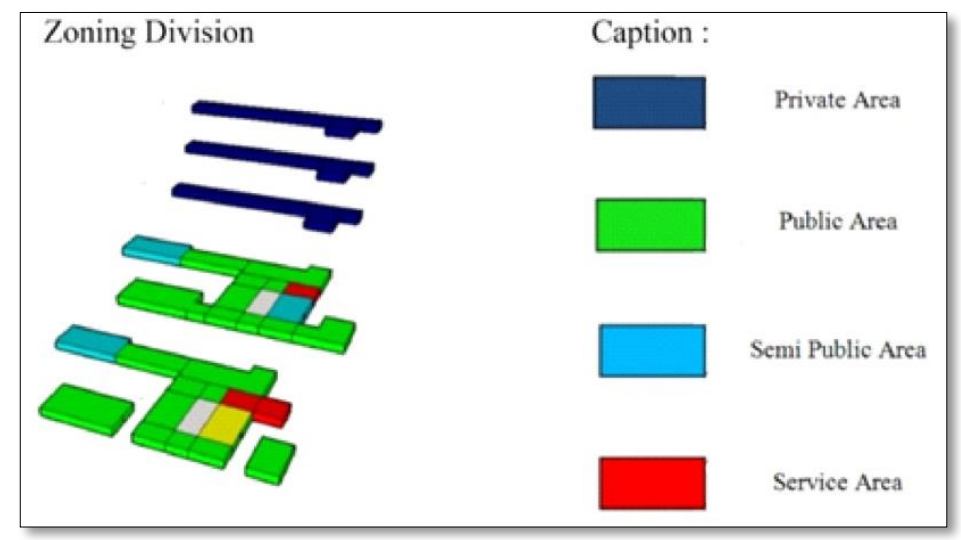

Figure 9. Zoning in Building

\section{The Concept of Circulation System}

In the circulation system in the guestroom hotel using a single loaded circulation to facilitate air circulation in the guestroom corridor. And also use two types of circulation that are horizontal circulation in the form of passage and vertical shape of stairs and elevators. Circulation on the floor area of the hotel ground plan is separated by the use of escalators and the application of voids to maximize space in the hotel (Figure 10).
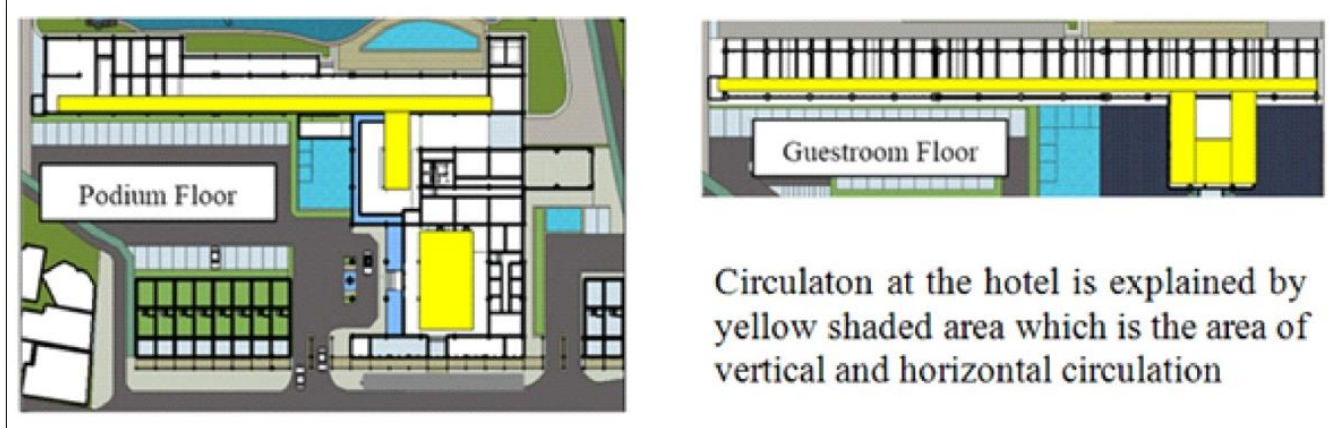

Circulaton at the hotel is explained by yellow shaded area which is the area of vertical and horizontal circulation

Figure 10. Circulation in Building

\section{The Concept of Structure}

The basic concept of structure and construction applied to this building uses bored pile foundation on the main building of hotel and palm foundation in heritage building and cottages. And also use the structure in general such as:/ columns, beams, ring beams, and dilatation. Column of the main building using column $80 \times 80 \mathrm{~cm}$ while in the heritage building and the cottage use column 40x40 cm (Figure 11). 


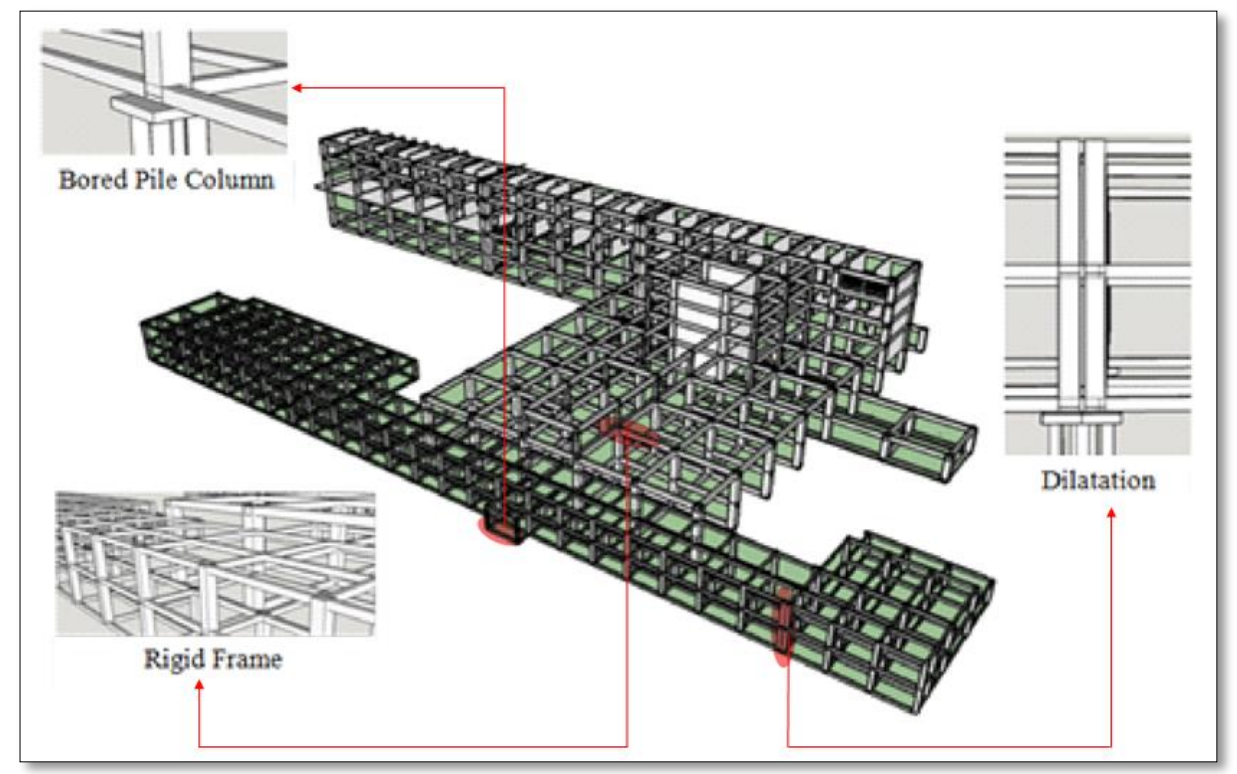

Figure 11. Concept of Structure

\section{The Concept of Architecture Design}

Integrated Zone of Cultural Heritage is located in Chinatown Medan Labuhan. This region applies the concept of vernacular architecture that is expected to revive the old atmosphere of the territory combined with the natural atmosphere. This area has four functions of buildings in it, namely: Market Center is the first function that is seen when entering the terrain in Medan Labuhan, then there is a Resort Hotel adjacent to Type C Hospital, and the last one to be a supporting facility to this area is Labuhan Train Station (Figure 12).

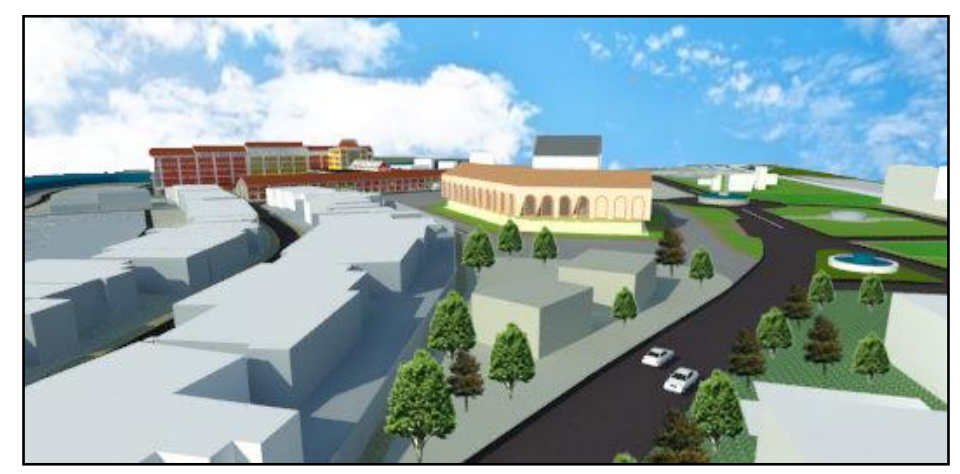

Figure 12. Entrance and Exit at Chinatown Area

This building is a blend of urban character and resort consisting of the main building of a resort hotel that looks more sturdy and with a distinctive roof including the Taopekong Sanctuary building that implements urban type architecture in Medan Labuhan. 


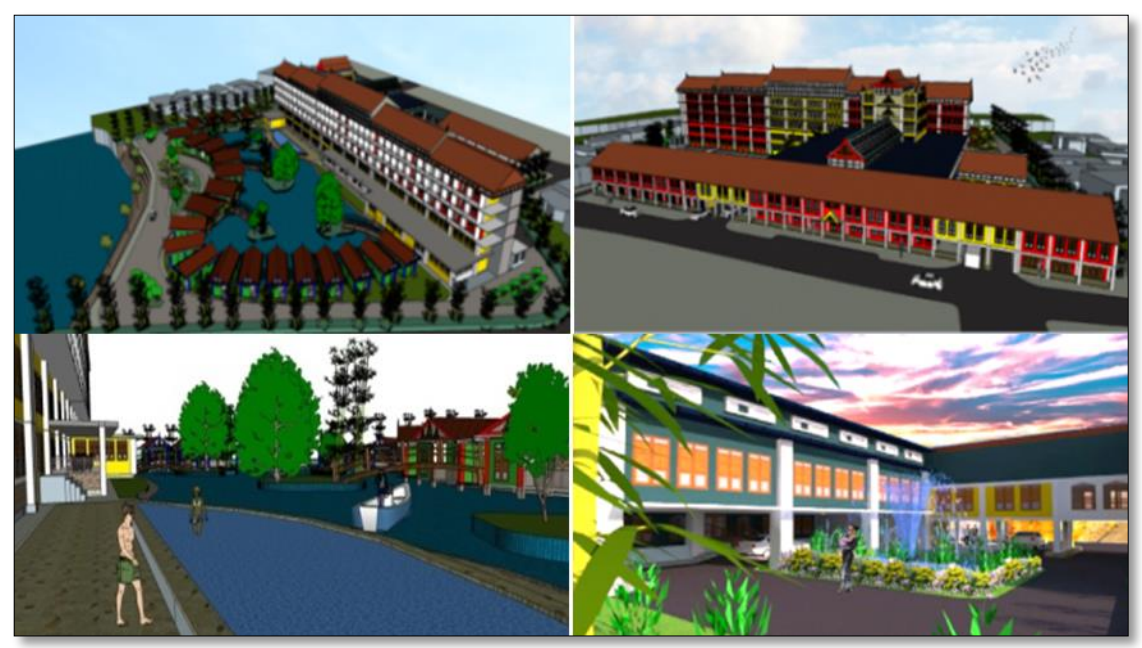

Figure 13. Perspective Exterior

Entrance in this area is obtained after passing Taopekong Culture Building located along Syahbudin Yatim Street. The atmosphere before entering the building visitors will be faced with a subway line of buildings on the left, and right side of the road is limited by old buildings, trees, pedestrian, parks, ornamental ponds and terraces in buildings (Figure 13).

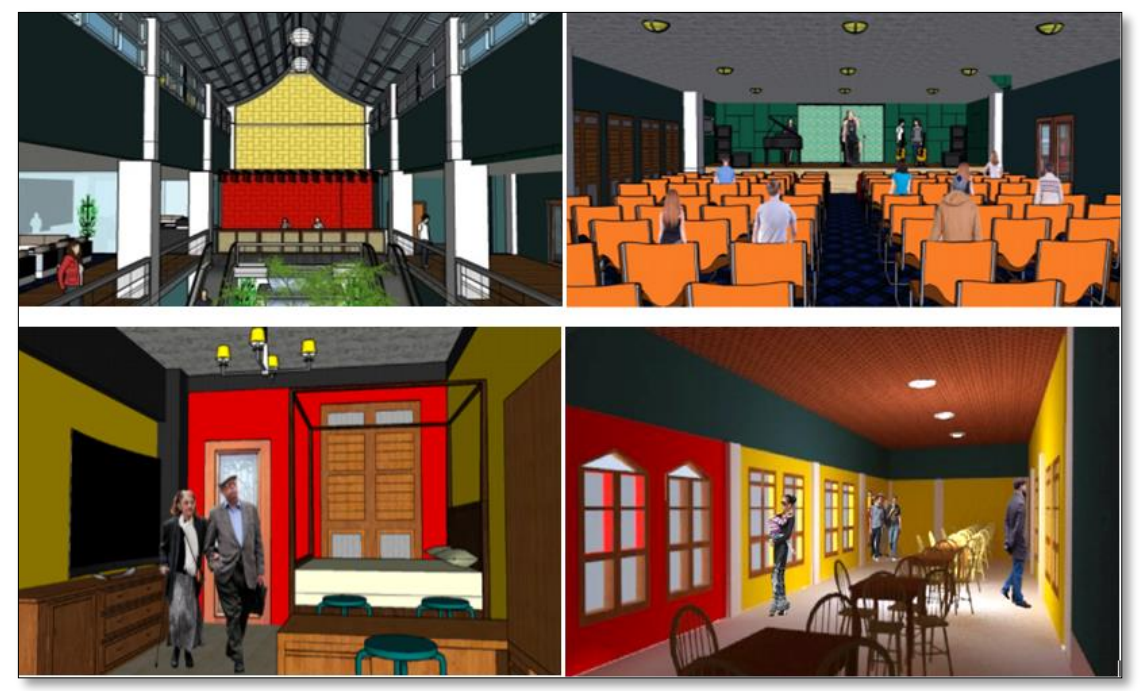

Figure 14. Perspective Interior

The major principle applied to the hotel is to protect the cultural heritage building of Taopekong building and unite it with the main function of resort hotels. However, still consider the modern materials in the construction of this hotel for both regarding architecture (Figure 14).

\section{Conclusion}

From the stages that have been done based on the literature study, survey and study search to appeal to the analysis, it can be concluded that this area is the Heritage Area and is the center of services and trade. So that has the potential to be done designing "Resort Hotel in Chinatown 
Medan Labuhan" with the application of vernacular theme that takes the characteristics of old buildings Taopekong in conservation into supporting facilities in this area and also can accommodate tourists who want to travel history in Chinatown Medan Labuhan.

\section{Acknowledgment}

This research is an original work of researcher as a suggestion for government to overcome problem in the development of historical areas as an effort to develop new tourism areas in Chinatown Labuhan, Medan - Indonesia.

\section{REFERENCES}

[1] Kristiningrum, N.D. Heritage Tourism and Creative Tourism. 2014.

[2] Lawson Fred. Hotel and Resorts: Planning, Design and Refurbishment. London: Architechture. 1995.

[3] Wiranto. Arsitektur Vernakular Indonesia: Perannya Dalam Pengendalian Jati Diri. Universitas Kristen Petra. 1999. 